\title{
PIWI Proteins and PIWI-Interacting RNA: Emerging Roles in Cancer
}

\author{
Yi-Neng Han ${ }^{a} \quad$ Yuan Li ${ }^{b} \quad$ Sheng-Qiang Xia ${ }^{b, c} \quad$ Yuan-Yuan Zhang ${ }^{d} \quad$ Jun-Hua Zheng ${ }^{e}$ \\ Wei Lib,d
}

aDepartment of General Dentistry, Shanghai Tenth People's Hospital, Tongji University, Shanghai, China; 'bepartment of Urology, Shanghai Tenth People's Hospital, Tongji University, Shanghai, China; 'Odense University Hospital, Department of Nephrology, University of Southern Denmark, Institute for Molecular Medicine, Cardiovascular and Renal Research Institute of Clinical Research, Odense, Denmark; dWake Forest Institute for Regenerative Medicine, Wake Forest University, NC, USA; eDepartment of Urology, Shanghai Jiao Tong University Affiliated First People's Hospital, Shanghai, China

\author{
Key Words \\ piRNAs • Cancer • Biomarkers • Therapy • Bioinformatics analysis
}

\begin{abstract}
P-Element induced wimpy testis (PIWI)-interacting RNAs (piRNAs) are a type of noncoding RNAs (ncRNAs) and interact with PIWI proteins. piRNAs were primarily described in the germline, but emerging evidence revealed that piRNAs are expressed in a tissue-specific manner among multiple human somatic tissue types as well and play important roles in transposon silencing, epigenetic regulation, gene and protein regulation, genome rearrangement, spermatogenesis and germ stem-cell maintenance. PIWI proteins were first discovered in Drosophila and they play roles in spermatogenesis, germline stem-cell maintenance, self-renewal, retrotransposons silencing and the male germline mobility control. A growing number of studies have demonstrated that several piRNA and PIWI proteins are aberrantly expressed in various kinds of cancers and may probably serve as a novel biomarker and therapeutic target for cancer treatment. Nevertheless, their specific mechanisms and functions need further investigation. In this review, we discuss about the biogenesis, functions and the emerging role of piRNAs and PIWI proteins in cancer, providing novel insights into the possible applications of piRNAs and PIWI proteins in cancer diagnosis and clinical treatment.

\section{Introduction}

Although more than $70 \%$ of the human genome is actively transcribed, only $1 \sim 2 \%$ of the human genome are protein-coding genes, and the major group of transcripts are noncoding

Y. Han and Y. Li are contributed equally to the article.

Jun-Hua Zheng,

and Wei Li 
RNAs (ncRNAs) [1]. ncRNA can be classified into two groups, including housekeeper ncRNAs and regulatory ncRNAs. Regulatory ncRNAs can be subdivided into small noncoding RNAs with transcripts shorter than 200 nucleotides and long noncoding RNAs (lncRNAs) with transcripts longer than 200 nucleotides. MicroRNAs (miRNAs), P-Element induced wimpy testis (PIWI) - interacting RNA (piRNAs), small interfering RNA (siRNAs) and small nucleolar RNA (snoRNA) all belong to small noncoding RNAs [2]. Among these regulatory small ncRNAs, miRNAs have been extensively studied, which can regulate gene expression via binding to the sequence of target mRNAs [3-5], while piRNAs are the newest type and are drawing increasing attention nowadays.

As a class of noncoding small RNA of 24-32 nucleotides, piRNAs are primarily named "repeat associated small interfering RNAs (rasiRNAs)" [6, 7]. But because of their interaction with PIWI subfamily of Argonaute proteins, they were formally defined as piRNAs in mammalian systems in 2006 [8-12]. By binding to PIWI proteins to form a piRNA/ PIWIcomplex, piRNAs exert a silencing effect in the PIWI-dependent transposon silencing, epigenetic regulation, gene and protein regulation, genome rearrangement, and germ stemcell maintenance [13-15]. At the same time, piRNAs serve a pivotal role in reproduction and fertility regulation [16-19], which were accumulated at the onset of meiosis or during spermatogenesis $[10,11]$.

PIWI proteins were first discovered in Drosophila [20], in which they play roles in germline stem-cell maintenance and self-renewal [21]. Here, PIWIs refers collectively to PIWI proteins, while Piwi refers to the individual protein. There are three type of Argonaute proteins including Aub, Piwi and AGO3 (endonucleases) in the germline cells, belonging to the PIWI subfamily of proteins $[22,23]$. As a nuclear protein, Piwi has important functions in retrotransposons silencing and the male germline mobility control [24]. In addition, Piwi is also involved in spermatogenesis [18]. Knockout mutations in Piwi proteins could result in defects in sperm development [24]. Recently, several studies have confirmed the function of piRNAs and PIWI proteins in cancer. However, there remain underlying functions and mechanisms of piRNAs and PIWI proteins requiring further elucidation.

In this review, we will first discuss about the biogenesis and functions of piRNAs. Then we talk about the piRNAs and PIWI proteins in cancer development, piRNA datasets as well as piRNA predictions, providing possible applications of piRNAs and PIWI proteins in cancer diagnosis and clinical treatment.

\section{Biogenesis of piRNAs}

Thereare mainly threegroups of piRNAsaccording tomultipleorigins:transposon-derived piRNAs, mRNA-derived piRNAs and lncRNAs-derived piRNAs. As the only well understood type of piRNAs, transposon-derived piRNAs are transcribed from both genomic strands and produce both sense and antisense piRNAs; mRNA-derived piRNAs are processed and often originate from 3' untranslated regions (UTRs); lncRNAs-derived piRNAs are produced from the entire transcript $[26,27]$. Unlike stem-loop or double-stranded precursors of miRNAs and siRNAs that are processed by the RNAse III Dicer, piRNAs are mostly transcribed as large (up to $200 \mathrm{~kb}$ ) single-stranded precursors, which are processed independently from Dicer ribonuclease [28-30]. There are no significant secondary structures of the stem-loop structures in piRNAs precursors detected in regions surrounding piRNAs which is different from miRNAs [31-33]. And piRNAs also don't show any phasing within a cluster sequence or overlap with each other like siRNAs [34]. Nevertheless, precursors of piRNAs also require further post transcriptional processing to become fully matured like other well investigated small regulatory ncRNAs.

There are mainly two mechanisms to generate mature piRNAs after transcription (Fig. 1): the primary synthesis mechanism and the 'ping-pong' amplification mechanism [27]. The primary transcript is first cleaved by the riboendonuclease Zucchini in the simplest scenario in Drosophila gonad somatic cells. The 3'fragment is incorporated in PIWI proteins and trimmed to a final length by a 3' to 5' exonuclease. The 2' hydroxy group at the 3 ' end is methylated by the enzyme Hen 1 while the $5^{\prime}$ end residue of the piRNA incorporated in PIWI 
Fig. 1. Biogenesis of piRNAs. There are mainly two mechanisms: the primary synthesis mechanism and the 'ping-pong' amplification mechanism to generating mature piRNAs after transcription. In the primary pathway, the primary transcript is first cleaved by the riboendonuclease Zucchini in the simplest scenario. The 3 'fragment is incorporated in PIWI proteins and trimmed to a final length by a 3 ' to 5' exonuclease. The 2' hydroxy group at the 3' end is methylated by the enzyme Hen 1 while the 5'end residue of the piRNA incorporated in

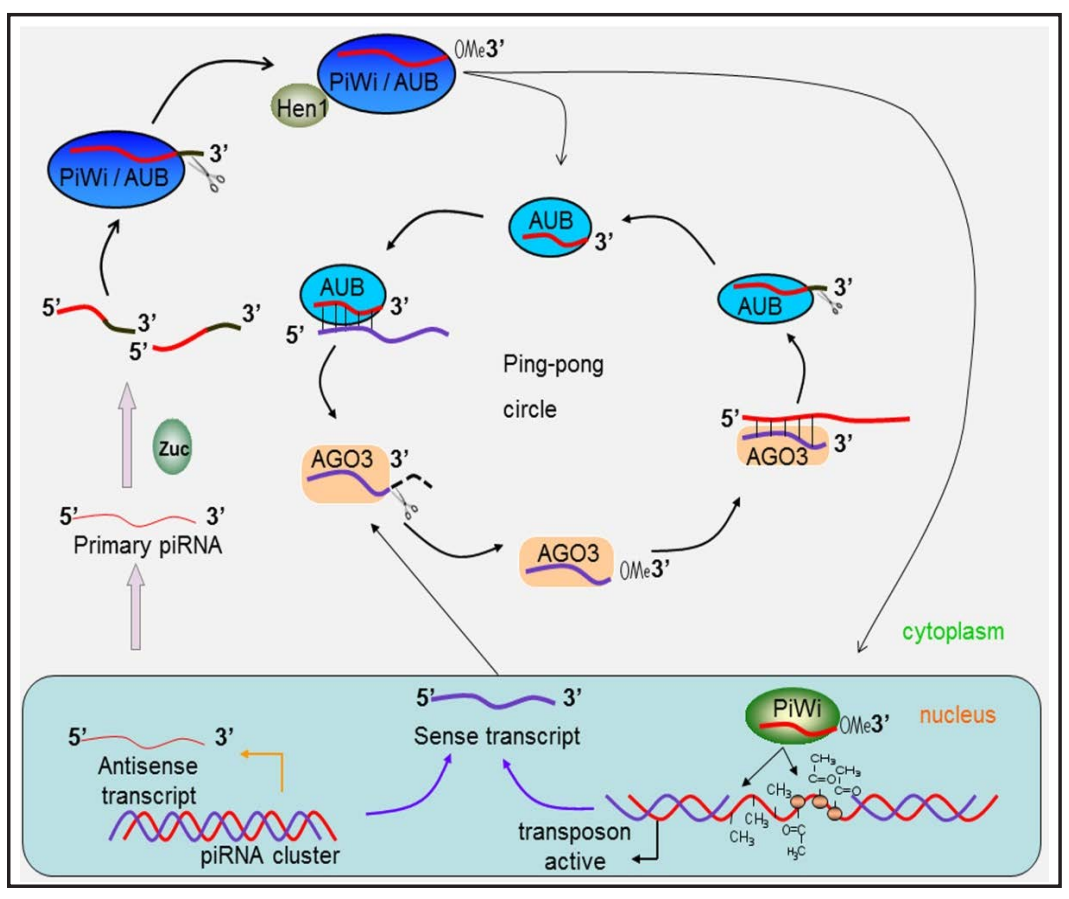
PIWI shows a strong favoring for uridine residues. After processed into final length, the piRNAs bind PIWI proteins respectively to form a piRNA/PIWI complex and migrate back to the nucleus. In the secondary pathway, piRNAs form piRNA/AGO or piRNA/AUB complexes, which contain complementary sequences and provide substrate to each other.

shows a strong bias for uridine residues. After processed into final length, the piRNAs bind PIWI proteins respectively to form a piRNA/PIWI complex [14]. Then the complex migrates back to the nucleus and reaches its target gene to mobilize silencer machinery to further block the transcription of that target gene through complementary base pairing of piRNAs and DNA. In this way, piRNAs are transcriptional regulators that act mainly on transposable element (TE) sequences by recruiting histone methyltransferases, which will lead to the establishment of transcriptionally silent heterochromatin [34].

After generating a primary piRNA, piRNA's accumulation needs amplification by the 'ping-pong' mechanism which occurs in the cytoplasm [14]. Different from the primary synthesis that associates with PIWI proteins, piRNAs join with AGO3 or AUB proteins to form piRNA/Ago or piRNA/Aub complexes, which contain complementary sequences to each other. piRNA/Ago complex can produce a sequence of RNA that will serve as a substrate for the formation of a new piRNA which is capable to load an Aub protein. Then the resulting piRNA/Aub protein complex will produce additional RNA substrates which form new piRNA/Ago3 complex in the same way. In other word, the products of piRNA in the cytoplasm provide substrate for another functional piRNA molecule, which is based on an amplification mechanism [35]. Ping-pong signatures have been identified in zebrafish, D. melanogaster and very primitive animals like sponges, indicating the 'ping-pong' cycle may exist in early evolutionary stage [36]. However, previous evidence showed that piRNAs biogenesis during adult spermatogenesis in mice is independent of the 'ping-pong' mechanism [37]. In mammals, piRNA/PIWI mechanisms show a diversity, which needs further exploration.

\section{Functions of piRNAs}

Actually, it is quite difficult to establish the functionality of piRNAs because of the wide variation in piRNA sequences and functions over species [38]. Up to now, piRNAs have been implicated in transposon silencing, epigenetic regulation, gene and protein regulation, 
genome rearrangement, spermatogenesis and germ stem-cell maintenance. Nevertheless, it still requires great endeavor to elucidate the specific functionalities of piRNAs.

\section{Transposons silencing}

piRNA has a role in RNA silencing via the formation of an RNA-induced silencing complex (RISC). It can direct the PIWI proteins to their transposon targets by binding to PIWI proteins [39]. A decreased or absent gene expression of PIWI lead to an increased expression of transposons [39]. Transposable elements (TEs) can be grouped into two types according to their mode of replication: 1) retrotransposons, which are transcribed into RNA intermediates; 2) DNA transposons, which do not need transcription to be mobilized [40]. TEs are found to have a high potential to cause deleterious effect on their host [41], contributing to genetic diversity and genetic instability $[42,43]$ and further leading to pathogenesis through gene deregulation, deleterious mutation and chromosome rearrangement as well as cancers [44]. The non-long terminal repeat (non-LTR) TEs can be classified into long interspersed elements (LINEs) and short interspersed elements (SINEs). non-LTR families L1, SVA, and Alu have been implicated in breast, colon, ovarian cancers and leukemia [45]. For instance, it has been proved that both in vivo and in vitro L1 insertions are involved in a diversity of cancer types [46]. The PIWI establishes a repressive chromatin state by increasing the trimethylation of the lysine-9 residue of histone-3 (H3K9me3) and HP1 chromatin marks at the transcriptional level [47]. Loss of piRNA has been linked to the loss of histone H3K9me3 and an increase in POL II occupancy at TEs [47]. And it has also been demonstrated that the recruitment of the heterochromatin protein HP1 to a piRNA reporter subject to transcriptional gene silencing (TGS) [47]. Then piRNA/PIWI complex recruits epigenetic factor HP1a and then HP1 recruit the histone methyltransferase Su(var)3-9 to the place that is responsible for most H3K9 methylation in Drosophila to exert functions [48] (Fig. 2). In the somatic tissues of developing embryos, retrotransposon Tirant initiated H3K9-mediated transcriptional gene silencing were against by maternally deposited piRNAs in Drosophila simulans [49]. Interestingly, a study found that genes containing or in proximity to TE sequences may be piRNA pathway targets. TE sequences are targeted by Piwi for silencing and transcriptional repression was closely related with the presence of a transposon or its remnants in an intron or in proximity to a gene [50,51]. These findings present us a Piwi-mediated TGS model where Piwi translocates to the nucleus to interact with nascent transcript or DNA at the target locus potentially, which in turn results in heterochromatin formation and transcriptional repression. Moreover, final silencing mark may not be the histone methylation. Current studies indicated that the high mobility group protein Maelstrom may act downstream of Piwi and histone methylation [50]. However, the exact role of Mael remains to be investigated.

In mammals, it has been demonstrated that the PIWI-like proteins Miwi2 is similar to the PIWI protein present in Drosophila [22] and both Mili and Miwi2 have an effect on the repetitive elements methylation and stable transposons repression maintenance in mice $[13,22]$. Furthermore, a decreased expression of piRNA cluster was correlated to an increase of TE activity [52]. Transposons silencing of piRNAs by DNA methylation could lead to transcriptional gene silencing. For instance, in the central nervous system (CNS) and other somatic tissues in Aplysia, piRNAs could induce CpG methylation and transcriptional silencing of a key plasticity related gene, CREB2 [53].

\section{Epigenetic activator}

In addition to take part in transposon silencing, a growing body of evidence indicates that Piwi can also serve as an epigenetic activator. In Drosophila, Piwi regulates chromosome 3R telomere-associated sequence (3R-TAS) positively and the absence of PIWI has an opposite genomic regulatory effects on different parts of the gene. For example, the absence of PIWI lead to enhanced telomere position effects in the white eye gene in Drosophila [54]. Piwi is need for the expression of 3R-TAS in a dose-dependent manner and can promote the active epigenetic state of 3R-TAS, implying an epigenetic activator role of Piwi [54]. However, 
Fig. 2. Epigenetic regulation of piRNA/Piwi pathway. A) In heterochromatin, piRNA/PIWI complex recruits epigenetic factor HP1a and then HP1 recruit the histone methyltransferase Su(var)3-9 to the place that is responsible for most H3K9 methylation to exert functions. Then Pol II transcription is inhibited and Piwi-piRNA target is silenced effectively by a critical mass of the H3K9 repressive chromatin marks through an unknown mechanism. B) In euchromatin, there are mainly two mechanisms.

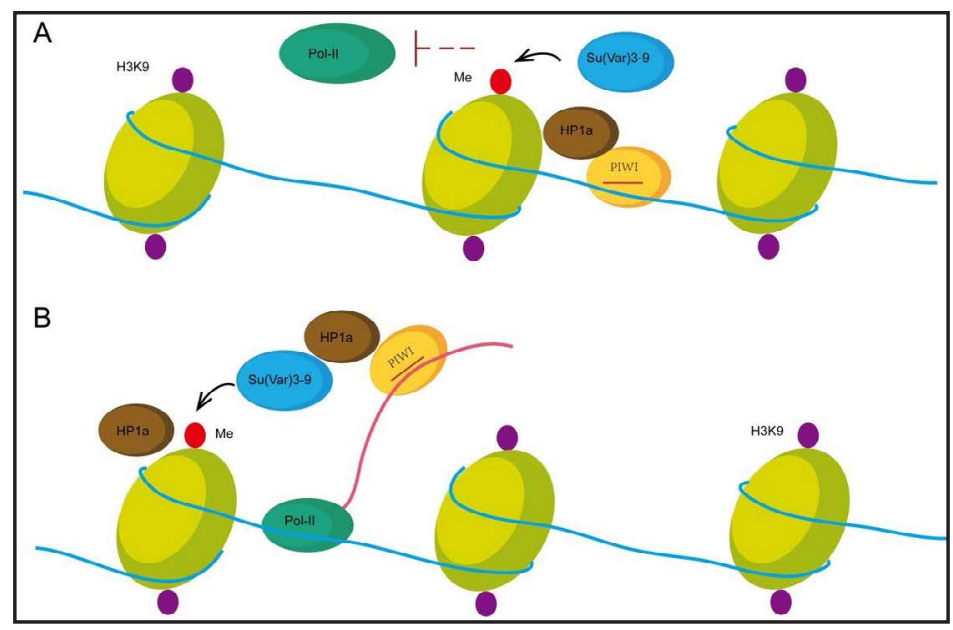
Piwi may first recruit the Su(var)3-

9and then HP1a bind the methylated H3K9. The other way is that Piwi may first recruit HP1a, and then HP1a recruits $\mathrm{Su}(\mathrm{var}) 3-9$ which deposits methyl groups on the unmethylated H3K9. Both working models have inhibitory effect on RNA Pol II transcription.

whether Piwi-binding lead to transcriptional silencing or activation may be correlated with what elements Piwi interacts with and/or is influenced by the local chromatin microenvironment or its sublocalization within the nucleus. The potential mechanisms need further exploration.

\section{Gene and protein regulators}

piRNA can also act as host gene and protein regulator. For example, piR_015520 is in intron 1 of the human melatonin receptor 1A gene (MTNR1A) gene, which has an altered expression in prostate cancer cells. piR_015520 has been shown negatively regulated MTNR1A gene expression by binding to its genomic region and overexpression of piR_015520 lead to a repression of MTNR1A expression in a concentration-dependent manner [53]. This data manifests that piRNA expression level alterations could influence the expression level of the gene where the piRNA is located, providing a novel insight of piRNAs as gene regulators in humans.

Analogically, piRNAs also regulate its interacting proteins stability by binding to it. For instance, piRNAs regulated Piwi protein Miwi ubiqutination by enhancing Miwi interaction with an APC/C substrate-binding subunit during late mouse spermatogenesis [17]. Mei et al. [55] identified 555 piRNAs in human lung bronchial epithelial (HBE) and non-small cell lung cancer (NSCLC) cell lines. The results indicated that 295 piRNAs were novel piRNAlike sncRNAs or piRNA-Ls. They found that piRNA/piRNA-L expressed aberrantly between HBE and NSCLC cells and among which piRNA-like-163 (piR-L-163) located in intron 10 of the LAMC2 gene is the most down-regulated. Further, they found that piR-L-163 binds directly to phosphorylated ERM proteins (p-ERM). The ERM proteins (ezrin, radixin and moesin) belong to a family of proteins located at cell cortex and they play critical role in regulating signal transduction pathways by connecting transmembrane proteins $[56,57]$. The piR-L-163/p-ERM interaction is critical for p-ERM's binding capability to filamentous actin (F-actin) and ERM-binding phosphoprotein 50 (EBP50). These data demonstrated that piRNA/piRNA-L may interact directly with proteins in physiological and pathophysiological conditions. Lee et al. [58] recently discovered the direct molecular interaction of piRNA-36026 with target geneserpin peptidase inhibitor, clade A, member 1 (SERPINA1) or lecithin retinol acyltransferase (LRAT), which are two tumor suppressor proteins and subsequent molecular therapeutic responses including caspase- 3 and phosphatidyl inositol (PI) in the nucleus by using a piR-36026 molecular beacon (MB).

\section{KARGER}




\section{Cellular Physiology Cell Physiol Biochem 2017;44:1-20

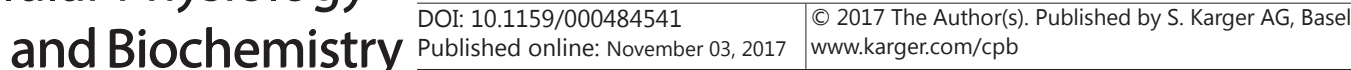 \\ Han et al.: PIWI Proteins and PIWI-Interacting RNA in Cancer}

\section{Other functions}

piRNAs are also involved in genome rearrangement. Genome rearrangement is also called somatic elimination. It is known as a process that the zygotic genome in each daughter cell is extensively edited to create a new and partial somatic genome that replaces the parental germline genome to prevent their transcription in the resultant macronuclei when conjugated [59]. For instance, Piwi orthologues are essential for proper genome rearrangement and piRNA production in the ciliate Tetrahymena. After mating, long noncoding RNAs transcribed from the parental somatic macronucleus act as sponges for germline-derived piRNAs. Thus, unbound piRNAs specifically mark any non-somatic regions in the genome for elimination in developing daughter macronucleus [60]. The genome rearrangement in ciliate Oxytricha is different from the ciliate Tetrahymena. Injection of RNAs that target normally deleted genes leads to their retention through multiple sexual generations, demonstrating that piRNAs are as powerful as trans-generational carriers of epigenetic information for genome programming [61]. Taken together, in Tetrahymena, the minority of the developing somatic genome is directed for deletion, whereas in Oxytricha the minority of the developing somatic genome is directed for retention.

In addition, the piRNA/PIWI pathway also has a direct role in buffering against phenotypic variation. It has been confirmed that Piwi depletion in Drosophila can lead to new somatic defects in a random fashion and at low frequency. It is already an agreement that the heat-shock protein Hsp90 is a key chaperone in suppressing phenotypic variation, depletion of which could generate various somatic phenotypic variants in species ranging from Arabidopsis [62] to Drosophila [63]. Drosophila Piwi forms a complex with Hsp90 and the heat-shock organizing protein, Hop, in vivo to serve as a phenotypic variation suppressor [64]. Furthermore, piRNAs also have functions in spermatogenesis, germ stem cell maintenance, etc. In murine spermatogenesis, it is observed that after the first stage of TE-derived piRNA production, in late stages of spermatogenesis piRNA recruit Miwi and deadenylase CAF1, a piRNA-induced silencing complex to assemble and induce mRNA deadenylation and degradation [65]. Clearly, Piwi has diverse roles in a variety of cellular processes, and it is challenging to further explore its potential functions. But it is believed that specific functions of piRNAs will be disclosed to improve our understanding on piRNAs in the near future.

piRNAs in cancer

Different from miRNAs, most piRNAs are not complementary to the mRNA of potential target genes, indicating that piRNAs may be involved in epigenetic regulation instead of post-transcriptional regulation for controlling diverse biologic phenomena, including cancer $[66,67]$. Epigenetic global alterations of cancers include DNA hypomethylation, histones hypoacetylation and gene-specific DNA hypermethylation, which results in oncogene activation (R-ras, cyclin D2) [68, 69] and tumor suppressor silencing (RB1, p16) [70]. Take a specific cell for example, only a restricted set of genes is active and is epigenetically regulated by a few piRNAs $[65,71]$, allowing a definition of unique tissue signatures, which is based on the profile of piRNAs expressed in a given tissue. In cancer tissues, aberrant expression of piRNAs implied by global hypomethylation and focal hypermethylation are probably potential cancer-specific signatures $[72,73]$. Accumulating evidence has revealed that several piRNAs have been implicated in cancer development, though only a small number of piRNAs have been found to express in somatic tissues at present [74]. Martinez et al. [74] analyzed 6, 260 human piRNA transcriptomes derived from non-malignant and tumor tissues from 11 organs and discovered that only 273 of the 20,831 known piRNAs are expressed in somatic non-malignant tissues and 522 piRNAs are expressed in corresponding tumor tissues, with a cancer-type specific manner. Altogether, piRNAs are involved in cancer cell proliferation, apoptosis, metastasis, invasion, and may be as potential prognostic and diagnostic biomarkers during cancer development (Table 1). 
Table 1. Summary of cancer-associated piRNAs

\begin{tabular}{|c|c|c|c|c|c|}
\hline piRNAs & Expression & Cancer & Function & Detection technique & Refere \\
\hline $\begin{array}{l}\text { piR-34736 } \\
\text { piR-36249 } \\
\text { piR-35407 } \\
\text { piR-36318 } \\
\text { piR-34377 } \\
\text { piR-36743 } \\
\text { piR-36026 } \\
\text { piR-31106 }\end{array}$ & Down-regulated & Breast cancer & $\begin{array}{l}\text { Influenced by cell cycle progression and the } \\
\text { oncosuppressive estrogen receptor } \beta \text { (ER } \beta \text { ) }\end{array}$ & Small RNAseq & [69] \\
\hline $\begin{array}{l}\text { piRABC } \\
\text { piR-823 }\end{array}$ & $\begin{array}{l}\text { Down-regulated } \\
\text { up-regulated }\end{array}$ & $\begin{array}{l}\text { Bladder cancer } \\
\text { Multiple myeloma }\end{array}$ & $\begin{array}{l}\text { Increase the expression of TNFSF } 4 \text { protein } \\
\text { Reduce DNA methyltransferases DNMT3A and 3B at both } \\
\text { mRNA and protein levels to decrease global DNA } \\
\text { methylation }\end{array}$ & $\begin{array}{l}\text { piRNA microarray } \\
\text { piRNA microarray }\end{array}$ & $\begin{array}{l}{[70]} \\
{[71]}\end{array}$ \\
\hline & Down-regulated & Gastric cancer & $\begin{array}{l}\text { Inhibit cancer cell growth, tumor-node-metastasis and } \\
\text { distant metastasis }\end{array}$ & piRNA microarray & {$[78,7 c$} \\
\hline piR-598 & Up-regulated & Glioma & Promote cell proliferation. & $\begin{array}{l}\text { GliomaScan genome-wide } \\
\text { association study (GWAS) }\end{array}$ & [72] \\
\hline piR-55490 & Down-regulated & lung cancer & $\begin{array}{l}\text { Suppress the activation of Akt/mTOR pathway by binding } \\
\text { 3'UTR of mTOR messenger RNA (mRNA) and induce its } \\
\text { degradation }\end{array}$ & - & [73] \\
\hline $\begin{array}{l}\text { piR-4987, } \\
\text { piR-20365, } \\
\text { piR-20485, } \\
\text { piR-20582 }\end{array}$ & Up-regulated & Breast cancer & $\begin{array}{l}\text { piR-4987 up-regulation was associated with lymph node } \\
\text { metastasis positivity }\end{array}$ & Deep sequencing & [74] \\
\hline piR-932 & up-regulated & Breast cancer & $\begin{array}{l}\text { Promote Latexin, methylation, and further promote } \\
\text { (epithelial-tomesenchymal transition) EMT, }\end{array}$ & piRNA microarray & [75] \\
\hline $\begin{array}{l}\text { piR-32051 } \\
\text { piR-39894 } \\
\text { piR-43607 }\end{array}$ & Up-regulated & $\begin{array}{l}\text { Clear cell renal cell } \\
\text { carcinoma (ccRCC) }\end{array}$ & $\begin{array}{l}\text { Associated with ccRCC metastasis, late clinical stage and } \\
\text { poor cancer-specific survival }\end{array}$ & Deep sequencing & {$[76]$} \\
\hline piR-021285 & Up-regulated & breast cancer & Increase ARHGAP11A mRNA expression and invasiveness & $\begin{array}{l}\text { single nucleotide } \\
\text { polymorphism (SNP) } \\
\text { selection }\end{array}$ & [77] \\
\hline piR-Hep1 & Up-regulated & $\begin{array}{l}\text { Hepatocellular } \\
\text { carcinoma }\end{array}$ & Increase the level of active AKT phosphorylation & Deep sequencing & {$[81]$} \\
\hline piR-651 & Up-regulated & $\begin{array}{l}\text { Gastric cancer } \\
\text { Lung cancer } \\
\text { Colon cancer } \\
\text { Breast cancer }\end{array}$ & Associated with T stage, meatstasis & piRNA microarray & {$[82]$} \\
\hline piR-57125 & Down-regulated & $\begin{array}{l}\text { Renal cell carcinoma } \\
\text { (RCC) [ }\end{array}$ & As independent prognostic predictors & piRNA microarray & {$[83]$} \\
\hline piR-30924 & Down-regulated & $\begin{array}{l}\text { Renal cell carcinoma } \\
\text { (RCC) }\end{array}$ & As independent prognostic predictors & piRNA microarray & [83] \\
\hline piR-38756 & Up-regulated & $\begin{array}{l}\text { Renal cell carcinoma } \\
\text { (RCC) }\end{array}$ & - & piRNA microarray & {$[83]$} \\
\hline $\begin{array}{l}\text { piR-59056 } \\
\text { piR-32105 } \\
\text { piR-58099 }\end{array}$ & Up-regulated & Gastric cancer & Associated with recurrence & $\begin{array}{l}\text { Analyzed by the Cancer } \\
\text { Genome Atlas (TCGA) }\end{array}$ & [84] \\
\hline $\begin{array}{l}\text { piR-59056 } \\
\text { piR-54878 }\end{array}$ & Up-regulated & Colon cancer & Associated with recurrence-free survival & $\begin{array}{l}\text { Analyzed by the Cancer } \\
\text { Genome Atlas (TCGA) }\end{array}$ & {$[84]$} \\
\hline $\begin{array}{l}\text { piR-62701 } \\
\text { piR-015551 }\end{array}$ & Down-regulated & Colorectal cancer & Associated with the LNC00964-3 expression levels & $\begin{array}{l}\text { Single nucleotide } \\
\text { polymorphism (SNP) } \\
\text { selection }\end{array}$ & [85] \\
\hline piR-017061 & Down-regulated & $\begin{array}{l}\text { Pancreatic ductal } \\
\text { adenocarcinoma }\end{array}$ & & Next-generation sequencing & {$[86]$} \\
\hline piR-L-163 & Down-regulated & Lung cancer & Bind directly to phosphorylated ERM proteins (p-ERM) & Small RNAseq & {$[52]$} \\
\hline
\end{tabular}

piRNAs are involved in cancer cell proliferation and apoptosis

Hashim et al. [75] identified more than 100 piRNAs expressed in breast cancer by analyzing smallRNA-Seq data generated from breast cancer cell lines and tumor biopsies, some of which were influenced by cell cycle progression and the oncosuppressive estrogen receptor $\beta$ (ER $\beta$ ). piR-34736, piR-36249, piR-35407, piR-36318 and piR-34377 were significantly down-regulated while piR-36743, piR-36026 and piR-31106 were dramatically up-regulated among 100 identified piRNAs. Further evidence suggested that piRNAs do exert transcriptional and post-transcriptional gene regulatory actions in cancer cells. In addition, most piRNAs are sensitive to estrogen and estrogen deficiency can lead to piRNA expression level alterations. As a novel type of estrogen receptor, ER $\beta$ can control the metastasis of cancer cells, directly regulating piRNA expression in breast cancer and responding to stimulations inside and outside cancer cells. Therefore, the estrogen deficiency and the effect of ER $\beta$ on piRNA can both inhibit the breast cancer cells growth. Chu et al [76]. used piRNA microarrays to investigate global piRNA expression in three bladder cancer tissues and their adjacent normal tissues. They found that the expression levels of 106 piRNAs were up-regulated and 91 were down-regulated in bladder cancer tissues, among which piRNA DQ594040 associated with bladder cancer (piRABC) is the most down-regulated. Over-expression of piRABC can inhibit bladder cancer cell proliferation, colony formation, and promote cell apoptosis though the up-regulation of TNFSF4 protein. piR-823 was found to be up-regulated in multiple myeloma (MM) patients and MM cell lines. PiR-823 was positively correlated with 
clinical stage, contrary to gastric cancer in which piR-823 was down-regulated. Silencing piRNA-823 in MM cells induced deregulation of cell cycle regulators and apoptosis-related proteins expression, and consequent tumorigenicity inhibition in vitro and in vivo. Moreover, piRNA-823 was directly related to de novo DNA methyltransferases, DNMT3A and 3B, in primary $\mathrm{CD} 138^{+} \mathrm{MM}$ cells. The inhibited expression of piRNA-823 in MM cells significantly reduced DNMT3A and 3B at both mRNA and protein levels, which in turn led to decrease in global DNA methylation and reexpression of methylation-silenced tumor suppressor, p16 ${ }^{\text {INK4A }}$. In addition, piRNA-823 abrogation in MM cells reduced vascular endothelial growth factor secretion, accompanied by decreased proangiogenic activity, suggesting an oncogenic role of piRNA-823 in the biology of MM [77]. Jacobs et al. [78] utilized directly measured and imputed genotypes from the GliomaScan genome-wide association study (GWAS) to analyze piRNAs associated with glioma risk and the results revealed that piR-598 impacted cell survival and reduced glioma cell viability and colony formation, which sharply promoted cell proliferation. Recently, piR-55490 was found to be silenced in lung carcinoma specimens and cell lines, compared with normal lung tissues and cells, and piR-55490 suppression led to the gain in the proliferation rate. Further study revealed that piR-55490 suppressed the activation of Akt/mTOR pathway by binding 3'UTR of mTOR messenger RNA (mRNA) and induce its degradation in a mechanism similar to miRNA in lung cancer cells [79]. These results facilitate our understanding of piRNA's functions and its role in cancer cell proliferation and apoptosis.

\section{piRNAs are involved in cancer cell metastasis and invasion}

To screen out differentially expressed piRNAs, deep sequencing was carried out in four breast cancer tissues and four matched non-tumor tissues. Then 4 piRNAs (piR-4987, piR20365, piR-20485 and piR-20582) were confirmed to be up-regulated by realtime RT-PCR in 50 breast cancer $(\mathrm{P}<0.001)$. Among them, piR-4987 up-regulation was positively associated with lymph node metastasis [80]. Another study showed that piR-932/PIWIL2 complex may positively regulate the process of breast cancer stem cells through promoting the methylation of Latexin, which in turn promotes epithelial-mesenchymal transition (EMT). Both piR-932 and PIWIL2 could be potential targets for blocking the metastasis of breast cancer [81]. By deep sequencing 24 frozen benign kidney and clear cell renal cell carcinoma (ccRCC) specimens and using the publically available piRNA database, Li et al. [82] found 19 piRNAs were differentially expressed between ccRCC and benign kidney tissue, and 46 piRNAs were associated with metastasis. Among these metastasis-related piRNAs, they found piR-32051, piR-39894 and piR-43607 were derived from the same piRNA cluster at chromosome 17, and were overexpressed in embryonic and neoplastic kidney cell lines compared to benign as well. Further studies showed that these three aberrantly expressed piRNAs were validated to be highly associated with ccRCC metastasis, late clinical stage and poor cancer-specific survival. Analogically, Fu et al. [83] found that piR-021285 is involved in methylation at a number of known breast cancer-related genes including attenuated 5' untranslated region (UTR)/first exon methylation at the proinvasive ARHGAP11A gene. Further studies revealed that both ARHGAP11A mRNA expression and invasiveness were concurrently increased in an in vitro cell line model. Cui et al. [84] observed that the levels of piR-823 in peripheral blood from patients with gastric cancer were remarkably lower than those in healthy controls and the expression level of piR-823 were positively associated with tumor-node-metastasis stage and distant metastasis, suggesting piRNAs may be valuable biomarkers for detecting circulating gastric cancer cells. Subsequently, Cheng et al. [85] found that overexpression of piR-823 could inhibited cancer cell growth. Further, xenograft nude mice model confirmed its tumor suppressive role in a dose-dependent manner, indicating that piR-823 play a crucial role in gastric cancer. Recently, Iliev et al. demonstrated that piR-823 is down-regulated in tumor tissue, blood serum and urine of renal cell carcinoma (RCC) [86]. Law et al. [87] identified a novel piR-Hep1 which is up-regulated in hepatocellular carcinoma (HCC) compared to adjacent non-malignant liver tissues through deep sequencing. PIWIL2 expression was positively correlated with the expression of piR-Hep1 in HCC, suggesting the oncogenic

\section{KARGER}




\section{Cellular Physiology Cell Physiol Biochem 2017;44:1-20 and BiOChemistry Published onlIne: November 03, 2017 \begin{tabular}{l|l} 
DOI: 10.1159/000484541 & $\begin{array}{l}\text { C } 2017 \text { The Author(s). Published by S. Karger AG, Basel } \\
\text { www.karger.com/cpb }\end{array}$
\end{tabular} \\ Han et al.: PIWI Proteins and PIWI-Interacting RNA in Cancer}

role piR-Hep1/PIWIL2 complexes. Silencing of piR-Hep1 inhibited cell viability, motility, and invasiveness, with a concomitant reduction in the level of active AKT phosphorylation, providing new insights into HCC tumorogenesis Therefore, piRNAs may play a key role in cancer cell metastasis and invasion, leading to cancer-related dysregulation.

\section{piRNAs as diagnostic and prognostic biomarkers}

Cheng et al. [88] used piRNA microarray to identify that piR-651 was significantly overexpressed in gastric cancer and then confirmed by PCR in a larger cohort of tumour and non-malignant tissues. The growth of gastric cancer cells was inhibited by a piR-651 inhibitor and arrested at the G2/M phase in a dose dependent manner, suggesting piR-651 may act as a potential marker for gastric cancer diagnosis. In addition, piR-651 was also confirmed to be up-regulated in other cancers including lung, colon, breast cancer tissues compared to paired noncancerous tissues. Busch et al. [89] identified 235 up-regulated and 369 down-regulated piRNAs in malignant tissue by piRNA microarray from 106 clear cell renal cell carcinomas patient samples. RT-qPCR analysis confirmed that piR-57125 was down-regulated in metastatic tumors while piR-30924 and piR-38756 were up-regulated in metastatic tumors. Furthermore, multivariate cox regression analyses revealed both piR30924 and piR-57125 could be regarded as independent prognostic predictors, especially in non-metastatic patients. More recently, Martinez et al. [90] analyzed the transcriptomes of 358 non-malignant stomach tissue and gastric adenocarcinoma samples, founding that nearly half of the expressed piRNAs were overexpressed in tumors, including piR-59056, piR-32105, and piR-58099, which was capable to separate patients by risk of recurrence effectively. Similarly, the association between piR59056, piR-54878, and piR-62701 and recurrence-free survival was also observed in colon cancer. Chu et al. [91] observed that mRNA expression levels of LNC00964-3 which is an lncRNA that included the piR-015551 sequence were significantly lower in colorectal cancer (CRC) tissues than in corresponding normal tissues. The expression of piR-015551 was positively correlated with the LNC009643 expression levels, indicating that piR-015551 may be possibly generated from LNC009643 , which may be involved in the development of CRC. piR-017061, located within HBII-296A snoRNA, revealed to be dramatically down-regulated in pancreatic ductal adenocarcinoma (PDAC) compared to nonmalignant pancreatic control tissues [92]. Currently, Krishnan et al. [93] discovered eight piRNAs as novel independent prognostic markers in breast cancer and their association with overall survival (OS) was confirmed in The Cancer Genome Atlas (TCGA) dataset. TCGA applies high-throughput genome analysis techniques to make us better understand the genetic bases of cancer [94]. The data showed that there are several piRNAs expressed in a cancer-related manner, offering evidence for the significance of piRNAs in diagnostic and clinical treatment. More importantly, piRNAs have an advantage of being short fragment, only 24-32 nt in length. This characteristic provides piRNAs an opportunity to pass through cell membrane easily instead of being degraded like other long RNAs and makes it detectable in patient samples like blood plasma and serum, saliva, sputum, and urine. A recent study found that piRNAs possess higher sensitivity and specificity compared to an existing miRNA-based biomarker detection system in gastric cancer [84]. Therefore, piRNAs are increasingly investigated to improve our understanding on the diagnosis of human cancers. Altogether, aberrantly expressed piRNAs in human cancers can be employed as a new class of diagnostic and prognostic biomarkers. There is an urgent need to shed light on the relationship between piRNAs and cancers in this promising field.

\section{PIWI proteins in cancer}

In addition to a role in cancer of piRNAs, PIWI proteins also play critical functions in tumorigenesis. There are four expressed PIWI proteins in humans: PIWIL1/HIWI, PIWIL2/ HILI, PIWIL3 and PIWIL4/HIWI2 [95]. Various studies have demonstrated that PIWI proteins are involved in cancer cell proliferation, apoptosis, metastasis, invasion and act as potential cancer diagnostic and prognostic biomarkers (Table 2). 
Table 2. Summary of cancer-associated PIWI proteins

\begin{tabular}{|c|c|c|c|c|}
\hline PIWI & Cancer & Expression & Function & Reference \\
\hline \multirow[t]{11}{*}{ PIWIL1/HIWI } & Seminoma & Up-regulated & Promote cell proliferation & [89] \\
\hline & Gastric cancer & Up-regulated & $\begin{array}{l}\text { Promote cell proliferation } \\
\text { related to poor prognosis }\end{array}$ & {$[90,107]$} \\
\hline & sarcomas & Up-regulated & Promote cell proliferation & {$[91]$} \\
\hline & Lung cancer & Up-regulated & Promote cell proliferation & [92] \\
\hline & Breast cancer & Up-regulated & Promote cell proliferation & [93] \\
\hline & Glioma & Up-regulated & $\begin{array}{l}\text { Promote cell proliferation, } \\
\text { metastasis and invasion }\end{array}$ & {$[94,105]$} \\
\hline & $\begin{array}{l}\text { Hepatocellular } \\
\text { carcinoma }\end{array}$ & Down -regulated & $\begin{array}{l}\text { Reduce cell proliferation } \\
\text { and migration; } \\
\text { Associated with prognosis }\end{array}$ & {$[95,106]$} \\
\hline & $\begin{array}{l}\text { Epithelial } \\
\text { ovarian cancer }\end{array}$ & Down-regulated & Repress cell invasiveness & {$[102]$} \\
\hline & Colorectal & Up-regulated & Inhibit migration and & {$[108,109]$} \\
\hline & Cancer & & $\begin{array}{l}\text { invasion; associated with } \\
\text { poor prognosis without } \\
\text { lymph node metastasis }\end{array}$ & \\
\hline & $\begin{array}{l}\text { Endometrial } \\
\text { cancer }\end{array}$ & Down-regulated & $\begin{array}{l}\text { Related to DNA } \\
\text { hypermethylation }\end{array}$ & [112] \\
\hline \multirow[t]{10}{*}{ PIWIL2/HILI } & $\begin{array}{l}\text { Soft-tissue } \\
\text { sarcoma }\end{array}$ & Down-regulated & $\begin{array}{l}\text { Reduce cell proliferation } \\
\text { and increase apoptosis }\end{array}$ & [96] \\
\hline & Several cancer & Up-regulated & $\begin{array}{l}\text { Promote tumor cell survival } \\
\text { and proliferation }\end{array}$ & {$[97]$} \\
\hline & $\begin{array}{l}\text { Cervical } \\
\text { squamous cell } \\
\text { Carcinomas }\end{array}$ & Up-regulated & Inhibit apoptosis & [103] \\
\hline & Colon cancer & Up-regulated & Promote metastasis & {$[104]$} \\
\hline & Breast cancer & Up-regulated & $\begin{array}{l}\text { Related to age, tumor size, } \\
\text { histological type, tumor } \\
\text { stage, and lymph node } \\
\text { metastasis }\end{array}$ & [75] \\
\hline & $\begin{array}{l}\text { Colorectal } \\
\text { cancer }\end{array}$ & $\begin{array}{l}\text { Down- } \\
\text { regulated(HILI) }\end{array}$ & $\begin{array}{l}\text { Inhibit migration and } \\
\text { invasion }\end{array}$ & [109] \\
\hline & & $\begin{array}{l}\text { Up- } \\
\text { regulated(PIWIL2) }\end{array}$ & Related to poor prognosis & [113] \\
\hline & Breast cancer & Up-regulated & Promote cell proliferation & [97] \\
\hline & Gastric cancer & Up-regulated & Related to poor prognosis & [107] \\
\hline & $\begin{array}{l}\text { Esophageal } \\
\text { cancer }\end{array}$ & Up-regulated & Related to poor prognosis & [110] \\
\hline PIWIL3 & Breast cancer & Up-regulated & prognostic relevance & {$[87]$} \\
\hline \multirow[t]{2}{*}{ PIWIL4/HIWI2 } & $\begin{array}{l}\text { Cervical } \\
\text { cancer }\end{array}$ & Up-regulated & $\begin{array}{l}\text { Impair apoptosis } \\
\text { Promote invasion }\end{array}$ & {$[100,101]$} \\
\hline & Breast cancer & Up-regulated & Prognostic relevance & [87] \\
\hline
\end{tabular}

PIWI proteins are involved in cancer cell proliferation and apoptosis

It was first reported that HIWI was significantly overexpressed in seminoma, a testicular germ-cell tumor [96]. Consequent studies found that in gastric cancer, the progressively increased expression of HIWI from preneoplastic lesions to advanced cancer suggests that HIWI was associated with the proliferation of gastric cancer cells [97]. Cellular differentiation was inhibited when HIWI was increased in sarcoma precursors and the growth was inhibited when HIWI was down-regulated. HIWI could decrease cellular differentiation state to keep indefinite proliferation and could inversely correlate with tumor suppressor genes (TSGs), such as p15, p21 and p27. Further studies showed that HIWI-associated DNA hypermethylation with subsequent genetic and epigenetic changes favoring a tumorigenic state [98]. In addition, HIWI gene was found to be highly expressed in the lung cancer stem cell population SSCloAldebr cells. Knockdown of HIWI gene remarkably impaired the sphere KARGER 
formation ability and colony forming capacity of SSCloAldebr cells, further suppressing the tumor growth of SSCloAldebr cells in nude mice [99]. The promoting roles of HIWI proteins in cell proliferation were also demonstrated in breast cancer [100]. In glioma, Wang et al. [101] found that silencing HIWI could inhibit cell proliferation by promoting apoptosis and increase cell cycle arrest, influencing the expression of apoptosis and cell cycle related proteins, including p21, cyclin D1, Bcl-2, and Bax. Furthermore, in hepatocellular carcinoma cell lines, Hiwi was found to be down-regulated, leading to reduction of proliferation and migration of these cells, indicating an oncogenic role in hepatocellular carcinoma [102]. Taubert et al. [103] demonstrated that PIWIL2 silencing could dramatically reduce tumor cell proliferation, colony formation but increase apoptosis in vitro, inhibiting tumor growth. Further, it was demonstrated that the effect of PIWIL2 on tumorgenesis is through the Stat3/Bcl-XL pathway [104]. Moreover, it is indicated that PIWIL2 could directly bind to STAT3 protein via its PAZ domain and form a PIWIL2/STAT3/c-Src triple protein-protein complex. Then STAT3 was phosphorylated by c-Src and translocated to nucleus, binding p53 promoter and repressing its transcription to reduce apoptosis in tumor cells [105]. As a splice isoform of PIWIL2, PIWIL2-like (PL2L) protein PL2L60 is mainly expressed in diverse kinds of human and mouse tumor cells. It was found that PL2L60 could take part in cell-cycle progression by promoting the G0/1 to S phase transition and further to promote tumor cell survival and proliferation by up-regulating the nuclear expression of NF- $\mathrm{KB}$, STAT3 and Bcl-2 [106]. PIWIL4 was also reported to play an oncogenic role in cervical cancer via impairing apoptosis through the p14ARF/p53 pathway to induce H3K9 methylation at the p14ARF locus without affecting the cell cycle in HeLa cells $[107,108]$. All these findings present us an important role of PIWI proteins in cancer cell proliferation and apoptosis.

\section{PIWI proteins are involved in cancer cell metastasis and invasion}

PIWIL1 had a repressive effect on cell invasiveness in epithelial ovarian cancer (EOC) [109]. Knockdown of HIWI was found to inhibit the migration and invasion of glioma cells by reducing the expression of MMP-2 and MMP 9, indicating HIWI is an oncogene involved in the progression of glioma [101]. On the contrary, PIWIL1 expression increased in metastasisdependent manner in hepatocellular carcinoma (HCC) [97]. PIWIL2 was detected in various stages of human cervical squamous cell carcinomas (CSCC) and atypical glandular cells (AGC), low-grade and high-grade squamous intraepithelial lesions, and have the potential to be used as a complementary marker for p16 (INK4a) [110]. Additionally, Li et al. [111] observed that PIWIL2 expressed higher in primary colon cancer tissue and colon cancer tissue with lymph node metastasis compared with normal colon mucosa. Higher expression of PIWIL2 was identified to be closely related to more aggressive clinical and pathological parameters, including five-year metastasis-free survival and overall survival. PIWIL2 knockdown also attenuated migration and invasion of colon cancer cells, regulating MMP9 transcriptional activities which can enhance migration and invasion of cancer cells [112]. Another study demonstrated that PIWIL2 was overexpressed significantly in breast cancer stem cells, and was associated with age, tumor size, histological type, tumor stage, and lymph node metastasis [81]. Moreover, PIWIL2 up-regulates RhoA, which in turn induces filamentary F-actin in a c-Myc-mediated manner. PIWIL4 can also promote cervical cancer cell invasion via down-regulating the expression of p14ARF and p53 [108]. Taking this evidence together, PIWI proteins are involved in cancer cell metastasis and invasion in tumorogenesis but specific mechanisms needs further investigation.

\section{PIWI proteins as diagnostic and prognostic biomarkers}

HIWI expression could be regarded as a potential biomarker for pathological diagnosis and prognosis for malignant gliomas and hepatocellular carcinoma (HCC) $[112,113]$. And it was also related to poor prognosis, with a poor 5-year survival of gastric cancer patients [114]. It has been identified that HIWI led to poor outcomes in colon adenocarcinoma patients without lymph node metastasis [115]. On the contrary, the expression of HILI mRNA was lower in colorectal cancer tissues compared to corresponding non-cancerous samples, 
indicating a reciprocal regulation between HIWI, HILI in colorectal cancer [116]. HILI is found to be expressed in breast cancer, colon cancer, gastrointestinal stromal tumors, renal cell carcinoma and endometrial carcinoma [104]. It was significantly related to histological grade, clinical stage and poorer clinical outcomes in esophageal cancer cells [117]. In addition, HILI was reported to be enriched in a cancer cell subpopulation expressing the stemness factors OCT4 and NANOG, consistent with the notion that PIWIs has a role in stem-cell maintenance and self-renewal [118]. Both PIWIL1 and PIWIL2 predicted poorer overall survival in gastric cancer tissue and PIWIL1 has been identified as an independent prognostic factor in gastric cancer [114]. PIWIL1 has been well demonstrated to mediate cancer development correlated with DNA hypermethylation. Chen et al. [119] found that PIWIL1 could promote the loss of PTEN expression which is an important tumor suppressor, and increase aberrant hypermethylation of PTEN gene promoter in Ishikawa cells through DNA methyltransferase 1 (DNMT1)-mediated PTEN hypermethylation in endometrial cancer. PIWIL2 expression was positively associated with colorectal cancer and was related to various clinic-pathologic parameters and a poor prognosis [120]. PIWIL2 showed different expression patterns in different stages of breast cancers. In both invasive and metastatic breast cancers, the cytoplasm, nucleus or both cytoplasm and nucleus, the expression of PIWIL2 can be observed but in breast pre-cancers, there are few PIWIL2 expressions in the nucleus, suggesting that PIWIL2 is likely to serve as a novel biomarker [121]. Yao et al. [122] showed that PIWIL2 can up-regulate c-Myc which serves as a crucial regulator in proliferation, invasion and metastasis among various human tumors via facilitating NME/ NM23 nucleoside diphosphate kinase 2 (NME2) to bind to G4-motif region within c-Myc promoter. Zeng et al. [123] indicated that the nuclear co-expression of Piwil2/Piwil4 had a worse prognostic phenotype in hepatocellular carcinoma, while a single marker (Piwil2/ Piwil4) cannot be used for prognosis judgment. PIWIL3 and PIWIL4 were currently showed prognostic relevance in breast cancer [93]. These observations provide potential importance of PIWI proteins in tumorigenesis. Nevertheless, how piRNAs interact with PIWI proteins to participate in tumorigenesis, invasion and metastasis needs further elucidation.

\section{piRNAs and PIWI interactions in cancer}

Although there are many studies reported on the expression pattern of piRNAs or PIWI proteins in tumorigenesis, few studies have investigated on the role of piRNAs interacting with PIWI proteins. It remains unclear whether PIWI proteins regulate cancer cell proliferation, apoptosis, metastasis and invasion in the cytoplasm independently or PIWI proteins perform epigenetic control of homeostasis by taken to the nucleus with piRNAs. Therefore, it takes scientists' effort to continue exploring underlying mechanisms between piRNAs and PIWI proteins in piRNA-related diseases.

Therapeutic insights into piRNAs and PIWI proteins

At present, there are several therapeutic methods designed according the characteristics of piRNAs (Fig. 3). The most appealing is the synthetic piRNAs which could block the synthesis of cancer related proteins by binding to mRNAs. Different from miRNAs, which need to be processed by enzymes and regulate several mRNAs [124], piRNAs have the advantage of not requiring enzymes processing and better specificity to targets. PIWI antibodies are another kind of speculative approach that could affect cancer proliferation clinically. Besides, it could be regarded as a post-translational approach in combinatory therapies for diverse cancers [125]. Actually, blocking the harmful component production may be better than antagonizing the undesired effects of an already functional molecule. Therefore, transcriptional silencing is an attractive direction and piRNAs are appropriate for its role in transcriptional silencing. Specific synthetic piRNAs are designed to bind PIWI proteins and exert genomic silencing on PIWI genes at transcriptional level. The cancer/testis antigens (CTAs) is a kind of tumor antigens and specifically expressed in normal testicular tissue, PIWI proteins could be a kind of CTAs because of its restrictive expression and function in tumorogenesis. Thus, another strategy is focus on the PIWI proteins. Reverse to the conventional 'ping-pong' mechanism of piRNA biogenesis that provide additional piRNAs to cause self-enhancement, 


\section{Cellular Physiology and BiOChemistry Published \begin{tabular}{l|l} 
DOI: 10.1159/000484541 & $\begin{array}{l}\text { C } 2017 \text { The Author(s). Published by S. Karger AG, Basel } \\
\text { www.karger.com/cpb }\end{array}$
\end{tabular}

Fig. 3. Cancer therapy via targeting piRNAs and PIWI proteins. Synthetic piRNAs could block the synthesis of cancer related proteins by binding to mRNAs in transcriptional and posttranscriptional methods. PIWI antibodies could affect cancer proliferation clinically at the post-translational level. The "piRNAi" are designed to bind PIWI proteins and exert genomic silencing on PIWI genes at transcriptional level when targeting DNA, while designed to contain specific sequence to be associated with proteins of the Argonaute family when targeting mRNA.

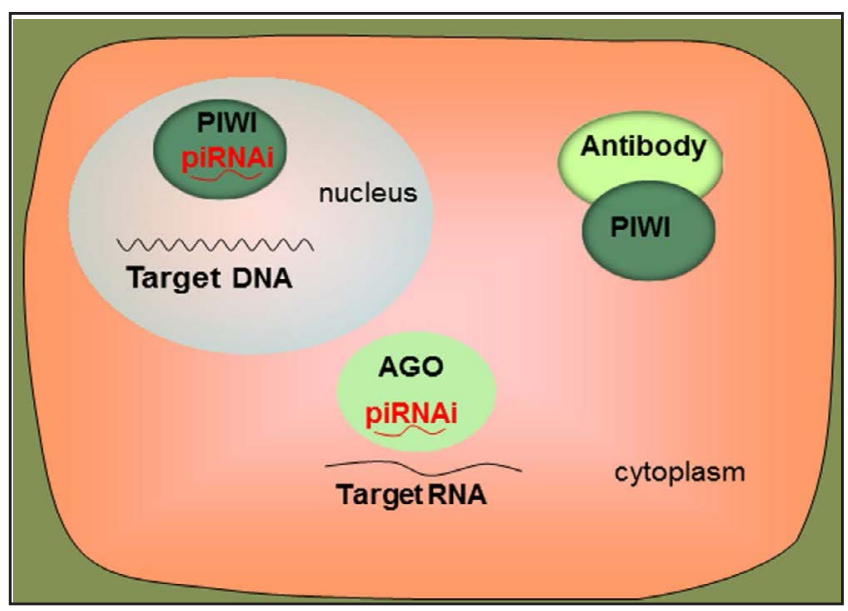

it inversely blocked the production of the PIWI protein [35, 126]. Previous studies have already demonstrated that the expression of PIWI proteins were negatively correlated with patients' survival, and inhibition of PIWI proteins could reduce the number of G2/M phase cells and enhance the expression of $\mathrm{p} 53$ protein, thus inhibiting proliferation and promoting apoptosis $[105,111]$. In addition, PIWI proteins can increase the resistance to chemotherapy drugs such as cisplatin, which is widely used to treat malignancies but has the limitation of dose-dependent nephrotoxicity [127]. Thus, decrease of the PIWI proteins expression could increase the sensitivity of cancer cells to cisplatin (CDDP), providing potential strategies to overcome chemoresistance for patients who receive chemotherapy [128]. For example, Wang et al. [129] recently identified the up-regulated PIWI-interacting RNA likes (piRLs) piR-L-138 upon chemoresistance to CDDP-based chemotherapy in lung squamous cell carcinoma (LSCC) and confirmed the enhanced sensitivity of LSCC to agents by targeting the up-regulated piR-L-138 both in vitro and in vivo.

In clinical treatment, the application of all there therapeutic strategies could be utilized in combination to make full use of each method; For instance, to decrease the side effects of conventional cytotoxic drugs and to improve the response to therapy, PIWI antibodies could be adopted to deliver drugs to cancer cells, which has been used in other antibodies as a delivery strategy [125]. Though the investigations of therapeutic methods on piRNAs are still on the initial stage, more and more therapeutic methods will be put into use with the understanding of the mechanisms and functions of piRNAs in cancer reinforced in the near future.

\section{piRNAs dataset and predictions}

The Indian scientists Sai Lakshmi S et al. [130] established the first piRNA databasepiRNABank, to save the new discovered piRNA sequences. piRNABank is a highly userfriendly resource which stores nearly 20 million empirically known sequences and other related information on piRNAs reported in human, mouse and rat. The database supports organism and chromosome-wise comprehensive search features including accession numbers, localization on chromosomes, gene name or symbol, sequence homology-based search, clusters and corresponding genes and repeat elements. It also displays each piRNA or piRNA cluster on a graphical genome-wide map (http://pirnabank.ibab.ac.in/). These databases make us better investigate and understand circRNAs and their association with diseases.

In addition to piRNA datasets, some studies have dedicated to analyze computational identification of piRNAs over the past few years. Betel et al. [131] trained a Support Vector Machine (SVM) classifier to distinguish between 5'-RNA and all other uridin positions for mouse piRNA sequences with a precision of 61-72 percent. But their method could not predict piRNA derived from the 3'-UTR of mRNA effectively which are produced by Ping Pong model. Zhang et al. [132] used Fisher separator algorithm by setting different cutoffs 
for piRNA identification in five model species including mice, humans, rats, fruit fly, and nematode with a precision of over $90 \%$ and a sensitivity of over $60 \%$. Brayet et al. [133] integrated machine learning method based on multiple kernels and SVM classifier to identify the human and Drosophila piRNAs. Wang et al. [134] performed transposon interaction and a SVM for piRNAs prediction to predict human, mouse and rat piRNAs with $90.6 \%$ accuracy. Seyeddokht et al. [135] proposed a prediction method to identify piRNA in human and 48 heterogeneous features (sequence and structural features). This novel method reached the accuracy of $99 \%$ on the benchmark dataset and revealed that the structural features are the most contributing features in piRNA prediction. Liu et al. [136] proposed a piRNA detection method based on sequence features including weighted k-mer, weighted k-mer with wildcards, position-specific base, and piRNA length. The piRNA sequences from human, mouse, rat, and drosophila were respectively used in this experiment. Compared to existing algorithms, the proposed method provided a better balance between precision and sensitivity (both are approximately 90\%). Although the precision and sensitivity were slightly slower than previous piRNA prediction approaches, this proposed method was four-fold faster than piRPred and 229-fold faster than piRNA predictor. Generally, the effectiveness of piRNA detection tools still requires improvement.

\section{Conclusion}

piRNAs were first recognized more than a decade ago and are coming into attention with the development of high-throughput sequencing technologies and bioinformatics methods, especially their gene regulatory function both in the nucleus and in the cytoplasm. Nevertheless, there is still lack of a complete and clear understanding of the functions and interactions of piRNAs and PIWI proteins. Therefore, the complicated biogenesis and functions of piRNAs need further elucidation to improve our understanding of them in diverse diseases. At present, piRNA has been recognized to express aberrantly in a cancerspecific manner, though there remain a majority of piRNAs to be investigated and specific molecular mechanisms to be explored. Despite many studies presented the aberrant expression pattern of piRNAs or PIWI proteins in cancer development, it remains unclear whether PIWI proteins regulate cancer cell proliferation, apoptosis, metastasis and invasion in the cytoplasm independently or PIWI proteins perform epigenetic control of homeostasis by taken to the nucleus with piRNAs. Discovering potential interactions may lead to novel discoveries of malignancy-associated pathways affected by altered piRNA expressions. Therefore, it would be possible to decipher underlying molecular functions that influence piRNA dysregulation in tumorogenesis by further understanding physiological functions. Furthermore, the available functions would deepen our understanding on therapeutic methods of piRNA in cancer. In the future, with scientists' endeavors and applications of new methods, many more piRNAs will be well identified and the mechanistic role of piRNA in tumour progression is sure to provide novel insight into the implication in cancer study.

\section{Acknowledgements}

This work was, in part, supported by Natural Science Foundation of China (No. 81602469) (to W-LI), and Natural Science Foundation of China (No. 31570775) (to JH-Z).

\section{Disclosure Statement}

The authors state that they have no Disclosure Statement to report in association with this article. 


\section{Cellular Physiology \begin{tabular}{ll|l} 
and Biochemistry & DOI: 10.1159/000484541 & $\begin{array}{l}\text { (c) } 2017 \text { The Author(s). Published by S. Karger AG, Basel } \\
\text { www.karger.com/cpb }\end{array}$ \\
\hline
\end{tabular}}

Han et al.: PIWI Proteins and PIWI-Interacting RNA in Cancer

\section{References}

1 Djebali S, Davis C A, Merkel A, Djebali S1, Davis CA, Merkel A, Dobin A, Lassmann T, Mortazavi A, Tanzer A, Lagarde J, Lin W, Schlesinger F, Xue C, Marinov GK, Khatun J, Williams BA, Zaleski C, Rozowsky J, Röder M, Kokocinski F, Abdelhamid RF, Alioto T, Antoshechkin I, Baer MT, Bar NS, Batut P, Bell K, Bell I, Chakrabortty S, Chen X, Chrast J, Curado J, Derrien T, Drenkow J, Dumais E, Dumais J, Duttagupta R, Falconnet E, Fastuca M, Fejes-Toth K, Ferreira P, Foissac S, Fullwood MJ, Gao H, Gonzalez D, Gordon A, Gunawardena H, Howald C, Jha S, Johnson R, Kapranov P, King B, Kingswood C, Luo OJ, Park E, Persaud K, Preall JB, Ribeca P, Risk B, Robyr D, Sammeth M, Schaffer L, See LH, Shahab A, Skancke J, Suzuki AM, Takahashi H, Tilgner H, Trout D, Walters N, Wang H, Wrobel J, Yu Y, Ruan X, Hayashizaki Y, Harrow J, Gerstein M, Hubbard T, Reymond A, Antonarakis SE, Hannon G, Giddings MC, Ruan Y, Wold B, Carninci P, Guigó R, Gingeras TR: Landscape of transcription in human cells. Nature 2012;489:101-108.

-2 Memczak S, Jens M, Elefsinioti A, Torti F, Krueger J, Rybak A, Maier L, Mackowiak SD, Gregersen LH, Munschauer M, Loewer A, Ziebold U, Landthaler M, Kocks C, le Noble F, Rajewsky N: Circular RNAs are a large class of animal RNAs with regulatory potency. J Oral Maxill Surg 2013;495:333-338. Bartel DP: MicroRNAs: genomics, biogenesis, mechanism, and function. Cell 2004;116:281-297. Calin G A, Croce CM: MicroRNA signatures in human cancers. Nat Rev Cancer 2006;6: 857-866. Shao Y, Geng Y, Gu W, Huang J, Pei H, Jiang J: Prognostic role of tissue and circulating microRNA-200c in malignant tumors: a systematic review and meta-analysis. Cell Physiol Biochem. 2015;35:1188-200.

6 Aravin AA, Lagos-Quintana M, Yalcin A, Zavolan M, Marks D, Snyder B, Gaasterland T, Meyer J, Tuschl T: The small RNA profile during Drosophila melanogaster development. Dev Cell 2003;5:337-350.

7 Theurkauf WE, Klattenhoff C, Bratu DP, McGinnis-Schultz N, Koppetsch BS, Cook HA. rasiRNAs, DNA damage, and embryonic axis specification. Cold Spring Harb Symp Quant Biol 2006;71:171-180.

8 Girard A, Sachidanandam R, Hannon GJ, Carmell MA A: germline-specific class of small RNAs binds mammalian Piwi proteins. Nature 2006;442:199-202.

-9 Vagin VV, Sigova A, Li C, Seitz H, Gvozdev V, Zamore PD: A distinct small RNA pathway silences selfish genetic elements in the germline. Science 2006;313:320-324.

-10 Aravin A, Gaidatzis D, Pfeffer S, Lagos-Quintana M, Landgraf P, Iovino N, Morris P, Brownstein MJ, Kuramochi-Miyagawa S, Nakano T, Chien M, Russo JJ, Ju J, Sheridan R, Sander C, Zavolan M, Tuschl T: A novel class of small RNAs bind to MILI protein in mouse testes. Nature 2006;442:203-207.

11 Grivna ST, Beyret E, Wang Z, Lin H: A novel class of small RNAs in mouse spermatogenic cells. Genes. Dev 2006;20:1709-1714.

12 Lau NC, Seto AG, Kim J, Kuramochi-Miyagawa S, Nakano T, Bartel DP, Kingston RE. Characterization of the piRNA complex from rat testes. Science 2006;313:363-367.

13 Aravin AA, Sachidanandam R, Girard A, Fejes-Toth K, Hannon GJ: Developmentally regulated piRNA clusters implicate MILI in transposon control. Science 2007;316:744-747.

-14 Brennecke J, Aravin AA, Stark A, Dus M, Kellis M, Sachidanandam R, Hannon GJ: Discrete small RNAgenerating loci as master regulators of transposon activity in Drosophila. Cell 2007;128:1089-1103.

15 Batista PJ, Ruby JG, Claycomb JM, Chiang R, Fahlgren N, Kasschau KD, Chaves DA, Gu W, Vasale JJ, Duan S, Conte Jr D., Luo S, Schroth GP, Carrington JC, Bartel DP, Mello CC: PRG-1 and 21U-RNAs interact to form the piRNA complex required for fertility in C. elegans. Mol Cell 2008;31:67-78.

-16 Schupbach T, Wieschaus E: Female sterile mutations on the second chromosome of Drosophila melanogaster. II. Mutations blocking oogenesis or altering egg morphology, Genetics 1991;129:1119-1136.

17 Cox DN, Chao A, Lin H: Piwi encodes a nucleoplasmic factor whose activity modulates the number and division rate of germline stem cells. Development 2000;127:503-514.

18 Deng W, Lin H: Miwi, a murine homolog of piwi, encodes a cytoplasmic protein essential for spermatogenesis. Dev Cell 2002;2:819-830.

19 Zhao S, Gou LT, Zhang M, Zu LD, Hua MM, Hua Y, Shi HJ, Li Y, Li J, Li D, Wang ED, Liu MF: PiRNA-triggered MIWI ubiquitination and removal by APC/C in late spermatogenesi. Dev Cell 2013;24:13-25.

20 Lin H, Spradling, AC: A novel group of pumilio mutations affects the asymmetric division of germline stem cells in the Drosophila ovary. Development 1997;124:2463-2476.

21 Cox, DN, Chao A, Baker J, Chang L, Qiao D, Lin H: A novel class of evolutionarily conserved genes defined by piwi are essential for stem cell self-renewal. Genes Dev 1998;12:3715-3727. 


\section{Cellular Physiology Cell Physiol Biochem 2017;44:1-20 \begin{tabular}{l|l|l} 
and Biochemistry & DOI: 10.1159/000484541 & $\begin{array}{l}\text { (c) } 2017 \text { The Author(s). Published by S. Karger AG, Basel } \\
\text { www.karger.com/cpb }\end{array}$
\end{tabular}

Han et al.: PIWI Proteins and PIWI-Interacting RNA in Cancer

22 Carmell MA, Girard A, van de Kant HJ, Bourc'his D, Bestor TH, de Rooij DG, Hannon GJ: MIWI2 is essential for spermatogenesis and repression of transposons in the mouse male germline. Dev Cell 2007;12:503514.

23 Gunawardane LS, Saito K, Nishida KM, Miyoshi K, Kawamura Y, Nagami T, Siomi H, Siomi MC: A slicermediated mechanism for repeat-associated siRNA 5'end formation in Drosophila. Science 2007;315:15871590.

-24 Saito K, Nishida KM, Mori T, Kawamura Y, Miyoshi K, Nagami T, Siomi H, Siomi MC: Specific association of Piwi with rasiRNAs derived from retrotransposon and heterochromatic regions in the Drosophila genome. Genes Dev 2006;20:2214-2222.

-25 Parker JS, Barford D: Argonaute: a scaffold for the function of short regulatory RNAs. Trends Biochem. Sci 2006;31:622-630.

26 Thomson T, Lin H: The biogenesis and function of PIWI proteins and piRNAs: progress and prospect. Annu Rev Cell Dev Biol 2009;25:355-376.

27 Weick EM, Miska EA: piRNAs, from biogenesis to function. Development 2014;141:3458-3471.

-28 Grishok A, Tabara H, Mello CC: Genetic requirements for inheritance of RNAi in C. elegans. Science 2000;287:2494-2497.

29 Gao Y, Feng B, Han S, Lu L, Chen Y, Chu X, Wang R, Chen L: MicroRNA-129 in Human Cancers: from Tumorigenesis to Clinical Treatment. Cell Physiol Biochem 2016;39:2186-2202.

-30 Pak J, Fire A: Distinct populations of primary and secondary effectors during RNAi in C. elegans. Science 2007;315:241-244.

31 Bartel DP: MicroRNAs: target recognition and regulatory functions. Cell 2009;136:215-233.

-32 Siomi MC, Sato K, Pezic D, Aravin AA: PIWI-interacting small RNAs: the vanguard of genome defence. Nat Rev Mol Cell Biol 2011;12:246-258.

-33 Masi LN, Serdan TD, Levada-Pires AC, Hatanaka E, Silveira LD, Cury-Boaventura MF, Pithon-Curi TC, Curi R, Gorjão R, Hirabara SM. Regulation of Gene Expression by Exercise-Related Micrornas. Cell Physiol Biochem 2016;39:2381-2397.

34 Luteijn MJ, Ketting RF: PIWI-interacting RNAs: from generation to transgenerational epigenetics. Nat Rev Genet 2013;14:523-534.

35 Ross RJ, Weiner MM, Lin H: PIWI proteins and PIWIinteracting RNAs in the soma. Nature 2014;505:353359.

-36 Grimson A, Srivastava M, Fahey B, Woodcroft BJ, Chiang HR, King N, Degnan BM, Rokhsar DS, Bartel DP: Early origins and evolution of microRNAs and Piwi-interacting RNAs in animals. Nature 2008;455:11931197.

37 Beyret E, Liu N, Lin H: PiRNA biogenesis during adult spermatogenesis in mice is independent of the pingpong mechanism. Cell Res 2012;22:1429-1439.

38 Wang G, Reinke V: A C. elegans Piwi, PRG-1, regulates 21U-RNAs during spermatogenesis. Current Biology 2008;18:861-867.

-39 Aravin AA, Sachidanandam R, Bourc'his D, Schaefer C, Pezic D, Toth KF, Bestor T, Hannon GJ: A piRNA Pathway Primed by Individual Transposons Is Linked to De Novo DNA Methylation in Mice. Molecular Cell 2008;31:785-799.

40 Hancks DC, Kazazian Jr HH: Active human retrotransposons: variation and disease. Curr Opin Genet Dev 2012;22:191-203.

-41 O’Donnell KA, Boeke JD: Mighty Piwis Defend the Germline against Genome Intruders. Cell 2007;129:3744.

42 Kazazian Jr HH: Mobile elements: drivers of genome evolution. Science 2004;303:1626-1632.

43 Cordaux R, Batzer MA: The impact of retrotransposons on human genome evolution. Nat Rev Genet 2009;10:691-703.

44 Chenais B: Transposable elements and human cancer: a causal relationship? Biochim Biophys Acta 2013;1835:28-35.

45 Konkel MK, Batzer MA: A mobile threat to genome stability: The impact of non-LTR retrotransposons upon the human genome. Semin Cancer Biol 2010;20:211-221.

-46 Lee E, Iskow R, Yang L, Gokcumen O, Haseley P, Luquette LJ 3rd, Lohr JG, Harris CC, Ding L, Wilson RK, Wheeler DA, Gibbs RA, Kucherlapati R, Lee C, Kharchenko PV, Park PJ: Cancer Genome Atlas Research Network. Landscape of somatic retrotransposition in human cancers. Science 2012;337:967-971. 


\section{Cellular Physiology Cell Physiol Biochem 2017;44:1-20

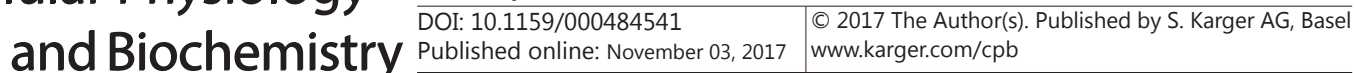

Han et al.: PIWI Proteins and PIWI-Interacting RNA in Cancer

47 Le Thomas A, Rogers AK, Webster A, Marinov GK, Liao SE, Perkins EM, Hur JK, Aravin AA, Tóth KF: Piwi induces piRNA-guided transcriptional silencing and establishment of a repressive chromatin state. Genes Dev 2013;27:390-399.

48 Huang XA, Yin H, Sweeney S, Raha D, Snyder M, Lin H: A major epigenetic programming mechanism guided by piRNAs. Dev Cell 2013;24:502-516.

-49 Akkouche A, Grentzinger T, Fablet M, Armenise C, Burlet N, Braman V, Chambeyron S, Vieira C: Maternally deposited germline piRNAs silence the tirant retrotransposon in somatic cells. EMBO Rep 2013;14:458464.

50 Sienski, G, Donertas, D, Brennecke, J: Transcriptional silencing of transposons by Piwi and Maelstrom and its impact on chromatin state and gene expression. Cell 2012;151:964-980.

51 Ohtani H, Iwasaki YW, Shibuya A, Siomi H, Siomi MC, Saito K: DmGTSF1 is necessary for Piwi-piRISCmediated transcriptional transposon silencing in the Drosophila ovary. Genes Dev 2013;27:1656-1661.

52 Xu M, You Y, Hunsicker P, Hori T, Small C, Griswold MD, Hecht NB: Mice deficient for a small cluster of Piwiinteracting RNAs implicate Piwi-interacting RNAs in transposon control. Biol Reprod 2008;79:51-57.

53 Esposito T, Magliocca S, Formicola D, Gianfrancesco F: PiR_015520 belongs to Piwi-associated RNAs regulates expression of the human melatonin receptor 1A gene. PLoS One 2011;6: e22727.

54 Yin H, Lin H. An epigenetic activation role of Piwi and a Piwi-associated piRNA in Drosophila melanogaster. Nature 2007;450:304-308.

- 55 Mei Y, Wang Y, Kumari P, Shetty AC, Clark D, Gable T, MacKerell AD, Ma MZ, Weber DJ, Yang AJ, Edelman MJ, Mao L: A piRNA-like small RNA interacts with and modulates p-ERM proteins in human somatic cells. Nat Commun 2015;6:7316.

56 Neisch AL, Fehon RG: Ezrin, Radixin and Moesin: key regulators of membrane-cortex interactions and signaling. Curr Opin Cell Biol 2011;23:377-382.

57 McClatchey AI, Fehon R G: Merlin and the ERM proteins-regulators of receptor distribution and signaling at the cell cortex. Trends Cell Biol. 2009;19:198-206.

58 Lee Y J, Moon S U, Park M G, Jung WY, Park YK, Song SK, Ryu JG, Lee YS, Heo HJ, Gu HN, Cho SJ, Ali BA, AlKhedhairy AA, Lee I, Kim S: Multiplex bioimaging of piRNA molecular pathway-regulated theragnostic effects in a single breast cancer cell using a piRNA molecular beacon. Biomaterials 2016;101:143-155.

59 Schoeberl UE, Mochizuki K: Keeping the soma free of transposons: programmed DNA elimination in ciliates. J Biol Chem 2011;286:37045-37052.

60 Aronica L, Bednenko J, Noto T, DeSouza LV, Siu KW, Loidl J, Pearlman RE, Gorovsky MA, Mochizuki K: Study of an RNA helicase implicates small RNA-noncoding RNA interactions in programmed DNA elimination in Tetrahymena. Genes Dev 2008;22:2228-2241.

61 Fang W, Wang X, Bracht JR, Nowacki M, Landweber LF: Piwi-interacting RNAs protect DNA against loss during Oxytricha genome rearrangement. Cell 2012;151:1243-1255.

62 Queitsch C, Sangster, TA, Lindquist S: Hsp90 as a capacitor of phenotypic variation. Nature 2002;417:618624.

63 Rutherford SL, Lindquist S: Hsp90 as a capacitor for morphological evolution. Nature 1998; 396:336-342.

-64 Gangaraju, V. K, Yin H, Weiner MM, Wang J, Huang XA, Lin H: Drosophila Piwi functions in Hsp90-mediated suppression of phenotypic variation. Nature Genet 2011;43:153-158.

65 Guo Z, Maki M, Ding R Yang Y, Zhang B, Xiong L: Genome-wide survey of tissue-specific microRNA and transcription factor regulatory networks in 12 tissues. Sci. Rep 2014;4:5150.

66 Kim VN: Small RNAs just got bigger: Piwi-interacting RNAs (piRNAs) in mammalian testes. Genes Dev 2006;20:1993-1997.

67 Wang QX, Zhu YQ Zhang H, Xiao J: Altered MiRNA expression in gastric cancer: a systematic review and meta-analysis. Cell Physiol Biochem 2015;35:933-44.

68 Feldman N, Gerson A, Fang J, Li E, Zhang Y, Shinkai Y, Cedar H, Bergman Y: G9a-mediated irreversible epigenetic inactivation of Oct-3/4 during early embryogenesis. Nat Cell Biol 2006;8:188-194.

69 Wilson AS, Power BE, Molloy PL: DNA hypomethylation and human diseases. Biochim Biophys Acta 2007;1775:138-162.

70 Baylin SB: DNA methylation and gene silencing in cancer. Nat Clin Pract Oncol 2005;2:S4-S11.

71 Esteller M: Cancer epigenomics, DNA methylomes and histone-modification maps. Nat Rev Genet 2007;8:286-298. 


\section{Cellular Physiology Cell Physiol Biochem 2017;44:1-20 \begin{tabular}{l|l|l} 
and Biochemistry & DOI: 10.1159/000484541 & $\begin{array}{l}\text { C } 2017 \text { The Author(s). Published by S. Karger AG, Basel } \\
\text { www.karger.com/cpb }\end{array}$
\end{tabular}

Han et al.: PIWI Proteins and PIWI-Interacting RNA in Cancer

72 Baylin SB, Jones PA: A decade of exploring the cancer epigenome - biological and translational implications. Nat Rev Cancer 2011;11:726-734.

73 Siddiqi S, Matushansky IJ: Piwis and piwi-interacting RNAs in the epigenetics of cancer. Cell Biochem 2012;113:373-380.

74 Martinez VD, Vucic EA, Thu KL, Hubaux R, Enfield KS, Pikor LA, Becker-Santos DD, Brown CJ, Lam S, Lam WL: Unique somatic and malignant expression patterns implicate PIWI-interacting RNAs in cancer-type specific biology. Sci Rep 2015;5:10423.

75 Hashim A, Rizzo F, Marchese G, Ravo M, Tarallo R, Nassa G, Giurato G, Santamaria G, Cordella A, Cantarella C, Weisz A: RNA sequencing identifies specific PIWI-interacting small non-coding RNA expression patterns in breast cancer. Oncotarget 2014;5:9901-9910.

-76 Chu H, Hui G, Yuan L, Shi D, Wang Y, Du M, Zhong D, Ma L, Tong N, Qin C, Yin C, Zhang Z6, Wang M: Identification of novel piRNAs in bladder cancer. Cancer Letters 2015;356:561-567.

-77 Yan H, Wu QL, Sun CY, Ai LS, Deng J, Zhang L, Chen L, Chu ZB, Tang B, Wang K, Wu XF, Xu J, Hu Y: piRNA-823 contributes to tumorigenesis by regulating de novo DNA methylation and angiogenesis in multiple myeloma. Leukemia 2015;29:196-206.

78 Jacobs DI, Qin Q Lerro M C, Fu A, Dubrow R, Claus EB, DeWan AT, Wang G, Lin H, Zhu Y: PIWI-interacting RNAs in Gliomagenesis: Evidence from Post-GWAS and Functional Analyses. CancerEpidem Biomark Prev 2016;25:1073-1080.

79 Peng L, Song L, Liu C, Lv X, Li X, Jie J, Zhao D, Li D: piR-55490 inhibits the growth of lung carcinoma by suppressing mTOR signaling. Tumor Biol 2016;37:1-8.

-80 Huang G, Hu H, Xue X, Shen S, Gao E, Guo G, Shen X, Zhang X: Altered expression of piRNAs and their relation with clinicopathologic features of breast cancer. Clin Transl Oncol 2013;15:563-568.

-81 Zhang H, Ren Y, Xu H, Pang D, Duan C, Liu C: The expression of stem cell protein Piwil2 and piR-932 in breast cancer. Surg Oncol 2013;22:217-223.

82 Li Y, Wu X, Gao H, Jin JM, Li AX, Kim YS, Pal SK, Nelson RA, Lau CM, Guo C, Mu B, Wang J, Wang F, Wang J, Zhao Y, Chen W, Rossi JJ, Weiss LM, Wu H: PIWI-interacting RNAs are dysregulated in renal cell carcinoma and associated with tumor metastasis and cancer specific survival. Mol Med 2015;21:381-388.

83 Fu A, Jacobs DI, Hoffman AE, Zheng T, Zhu Y: PIWI-interacting RNA 021285 is involved in breast tumorigenesis possibly by remodeling the cancer epigenome. Carcinogenesis 2015;36:1094-1102.

-84 Cui L, Lou Y, Zhang X, Zhou H, Deng H, Song H, Yu X, Xiao B, Wang W, Guo J: Detection of circulating tumor cells in peripheral blood from patients with gastric cancer using piRNAs as marks. Clin Biochem 2011;44:1050-1057.

85 Cheng J, Deng H, Xiao B, Zhou H, Zhou F, Shen Z, Guo J: piR-823, a novel non-coding small RNA, demonstrates in vitro and in vivo tumor suppressive activity in human gastric cancer cells. Cancer Lett 2012;315:12-17.

-86 Iliev R, Fedorko M, Machackova T, Mlcochova H, Svoboda M , Pacik D, Dolezel J, Stanik M, Slaby O: Expression Levels of PIWI-interacting RNA, piR-823, Are Deregulated in Tumor Tissue, Blood Serum and Urine of Patients with Renal Cell Carcinoma. Anticancer Res 2016;36:6419-6423.

-87 Law PT, Qin H, Ching AK, Lai KP, Co NN, He M, Lung RW, Chan AW, Chan TF, Wong N: Deep sequencing of small RNA transcriptome reveals novel non-coding RNAs in hepatocellular carcinoma. J Hepatol 2013;58:1165-1173.

88 Cheng J, Guo JM, Xiao BX, Miao Y, Jiang Z, Zhou H, Li QN: piRNA, the new non-coding RNA, is aberrantly expressed in human cancer cells. Clin Chim Acta 2011;412:1621-1625.

89 Busch J, Ralla B, Jung M, Wotschofsky Z, Trujillo-Arribas E, Schwabe P, Kilic E, Fendler A, Jung K: Piwiinteracting RNAs as novel prognostic markers in clear cell renal cell carcinomas. J Exp Clin Cancer Res 2015;34:61.

90 Martinez VD, Enfield KS, Rowbotham DA, Lam WL: An atlas of gastric PIWIinteracting RNA transcriptomes and their utility for identifying signatures of gastric cancer recurrence. Gastric Cancer 2015;19:660-665.

-91 Chu H, Xia L, Qiu X, Gu D, Zhu L, Jin J, Hui G, Hua Q, Du M, Tong N, Chen J, Zhang Z, Wang M: Genetic variants in noncoding PIWI-interacting RNA and colorectal cancer risk. Cancer 2015;121:2044-2052.

92 Müller S, Raulefs S, Bruns P, Afonso-Grunz F, Plötner A, Thermann R, Jäger C, Schlitter AM, Kong B, Regel I, Roth WK, Rotter B, Hoffmeier K, Kahl G, Koch I, Theis FJ, Kleeff J, Winter P, Michalski CW: Next-generation sequencing reveals novel differentially regulated mRNAs, IncRNAs, miRNAs, sdRNAs and a piRNA in pancreatic cancer. Mol Cancer 2015;14:144. 


\section{Cellular Physiology Cell Physiol Biochem 2017;44:1-20 and Biochemistry Published onIne: November 03, 2017 \begin{tabular}{l|l} 
DOI: 10.1159/000484541 2017 The Author(s). Published by S. Karger AG, Basel \\
www.karger.com/cpb
\end{tabular}}

Han et al.: PIWI Proteins and PIWI-Interacting RNA in Cancer

93 Krishnan P, Ghosh S, Graham K, Mackey JR, Kovalchuk O, Damaraju S: Piwi-interacting RNAs and PIWI genes as novel prognostic markers for breast cancer Oncotarget 2016 7:37944-37956.

$\$ 94$ Mclendon R, Friedman A, Bigner D, et al: Comprehensive genomic characterization defines human glioblastoma genes and core pathways. Nature 2008;455:1061-1068.

-95 Sasaki T, Shiohama A, Minoshima S, Shimizu N: Identification of eight members of the Argonaute family in the human genome. Genomics 2003;82:323-330.

-96 Qiao, D, Zeeman AM, Deng W, Looijenga LH, Lin H: Molecular characterization of hiwi, a human member of the piwi gene family whose overexpression is correlated to seminomas. Oncogene 2002;21:3988-3999.

-97 Liu X, Sun Y, Guo J, Ma H, Li J, Dong B, Jin G, Zhang J, Wu J, Meng L, Shou C: Expression of Hiwi gene in human gastric cancer was associated with proliferation of cancer cells. Int J Cancer 2006;118:1922-1929.

-98 Siddiqi S, Terry M, Matushansky I: Hiwi mediated tumorigenesis is associated with DNA hypermethylation. PLoS One 2012;7:e33711.

99 Liang D, Yang Y, Liu Y: The role Hiwi gene in the maintenance of lung cancer stem cell populations. Neoplasma DOI: 10.4149/neo_2014_022.

100 Wang DW, Wang ZH, Wang LL, Song Y, Zhang GZ: Overexpression of hiwi promotes growth of human breast cancer cells. Asian Pacific J Cancer Prev 2014;15:7553-7558.

101 Wang X, Tong X, Gao H, Yan X, Xu X, Sun S, Wang Q, Wang J: Silencing HIWI suppresses the growth, invasion and migration of glioma cells. Int J Oncol 2014;45:2385-2392.

102 Xie Y, Yang Y, Ji D, Zhang D, Yao X, Zhang X: Hiwi downregulation, mediated by shRNA, reduces the proliferation and migration of human hepatocellular carcinoma cells. Mol Med Rep 2015;11:1455-1461.

103 Taubert H, Greither T, Kaushal D, Würl P, Bache M, Bartel F, Kehlen A, Lautenschläger C, Harris L, Kraemer K, Meye A, Kappler M, Schmidt H, Holzhausen HJ, Hauptmann S: Expression of the stem cell self-renewal gene Hiwi and risk of tumour-related death in patients with soft-tissue sarcoma. Oncogene 2007;26:10981100.

104 Lee JH, Schutte D, Wulf G, Fuzesi L, Radzun HJ, Schweyer S, Engel W, Nayernia K: Stem-cell protein Piwil2 is widely expressed in tumors and inhibits apoptosis through activation of Stat3/Bcl-XL pathway. Hum Mol Genet 2006;15:201-211.

105 Lu Y, Zhang K, Li C, Yao Y, Tao D, Liu Y, Zhang S, Ma Y: Piwil2 suppresses p53 by inducing phosphorylation of signal transducer and activator of transcription 3 in tumor cells. PLoS One 2012; 7:e30999.

106 Ye Y, Yin DT, Chen L, Zhou Q Shen R, He G, Yan Q Tong Z, Issekutz AC, Shapiro CL, Barsky SH, Lin H, Li JJ, Gao JX: Identification of Piwil2-like (PL2L) proteins that promote tumorigenesis. PLoS One 2010;5:e13406.

107 Sugimoto K, Kage H, Aki N, Sano A, Kitagawa H, Nagase T, Yatomi Y, Ohishi N, Takai D: The induction of H3K9 methylation by PIWIL4 at the p16Ink4a locus. Biochem Biophys Res Commun 2007;359:497-502.

108 Su C, Ren ZJ, Wang F, Liu M, Li X, Tang H: PIWIL4 regulates cervical cancer cell line growth and is involved in down-regulating the expression of p14ARF and p53 FEBS Lett 2012;586:1356-1362.

109 Lim SL, Ricciardelli C, Oehler MK, Tan IM, Russell D, Grutzner F: Overexpression of piRNA pathway genes in epithelial ovarian cancer. PLoS One 2014;9:e99687.

110 He G, Chen L, Ye Y, Xiao Y, Hua K, Jarjoura D, Nakano T, Barsky SH, Shen R, Gao JX: Piwil2 expressed in various stages of cervical neoplasia is a potential complementary marker for $\mathrm{p} 16$. Am J Transl Res 2010;2:156-169.

111 Li D, Sun X, Yan D, Huang J, Luo Q, Tang H, Peng Z: Piwil2 modulates the proliferation and metastasis of colon cancer via regulation of matrix metallopeptidase 9 transcriptional activity. Exp Biol Med (Maywood) 2012;237:1231-1240.

112 Sun G, Wang Y, Sun L, Luo H, Liu N, Fu Z, You Y: Clinical significance of Hiwi gene expression in gliomas. Brain Res 2011;1373:183-188.

113 Zhao YM, Zhou JM, Wang LR, He HW, Wang XL, Tao ZH, Sun HC, Wu WZ, Fan J, Tang ZY, Wang L: HIWI is associated with prognosis in patients with hepatocellular carcinoma after curative resection. Cancer 2012;118:2708-2717.

114 Wang Y, Liu Y, Shen X, Zhang X, Chen X, Yang C, Gao H: The PIWI protein acts as a predictive marker for human gastric cancer. Int J Clin Exp Pathol 2012;25:315-325.

115 Liu C, Qu L, Dong B, Xing X, Ren T, Zeng Y, Jiang B, Meng L, Wu J, Shou C: Combined phenotype of 4 markers improves prognostic value of patients with colon cancer. Am J Med Sci 2012;343:295-302. 


\section{Cellular Physiology Cell Physiol Biochem 2017;44:1-20 \begin{tabular}{l|l|l} 
and Biochemistry 10.1159/000484541 & $\begin{array}{l}\text { C } 2017 \text { The Author(s). Published by S. Karger AG, Basel } \\
\text { www.karger.com/cpb }\end{array}$ \\
\hline
\end{tabular}

Han et al.: PIWI Proteins and PIWI-Interacting RNA in Cancer

-116 Litwin M, Dubis J, Arczyńska K, Piotrowska A, Frydlewicz A, Karczewski M, Dzięgiel P, Witkiewicz W: Correlation of HIWI and HILI Expression with Cancer Stem Cell Markers in Colorectal Cancer. Anticancer Res 2015;35:3317-3324.

117 He W, Wang Z, Wang Q, Fan Q, Shou C, Wang J, Giercksky KE, Nesland JM, Suo Z: Expression of HIWI in human esophageal squamous cell carcinoma is significantly associated with poorer prognosis. BMC Cancer 2009;9:426.

118 Lee, JH, Jung C, Javadian-Elyaderani P, Schweyer S, Schütte D, Shoukier M, Karimi-Busheri F, Weinfeld M, Rasouli-Nia A, Hengstler JG, Mantilla A, Soleimanpour-Lichaei HR, Engel W, Robson CN, Nayernia K: Pathways of proliferation and antiapoptosis driven in breast cancer stem cells by stem cell protein Piwil2 Cancer Res 2010;70:4569-4579.

119 Chen Z, Che Q Jiang FZ, Wang HH, Wang FY, Liao Y, Wan XP: Piwil1 causes epigenetic alteration of PTEN gene via upregulation of DNA methyltransferase in type I endometrial cancer. Biochem Biophys Res Comm 2015;463:876-880.

120 Oh SJ, Kim SM, Kim YO, Chang HK: Clinicopathologic implications of PIWIL2 expression in colorectal cancer. Korean J Pathol 2012;46:318-323.

121 Liu JJ, Shen R, Chen L, Ye Y, He G, Hua K, Jarjoura D, Nakano T, Ramesh GK, Shapiro CL, Barsky SH, Gao JX: Piwil2 is expressed in various stages of breast cancers and has the potential to be used as a novel biomarker. Int J Clin Exp Pathol 2010;3:328-337.

122 Yao Y, Li C, Zhou X, , Zhang Y, Lu Y, Chen J, Zheng X, Tao D, Liu Y, Ma Y: PIWIL2 induces c-Myc expression by interacting with NME2 and regulates c-Myc-mediated tumor cell proliferation. Oncotarget 2014;5:84668477.

123 Zeng G, Zhang D, Liu X, Kang Q, Fu Y, Tang B, Guo W, Zhang Y, Wei G, He D: Co-expression of Piwil2/Piwil4 in nucleus indicates poor prognosis of hepatocellular carcinoma. Oncotarget 2017;8:4607-4617.

124 Xie T, Huang M, Wang Y, Wang L, Chen C, Chu X. MicroRNAs as Regulators, Biomarkers and Therapeutic Targets in the Drug Resistance of Colorectal Cancer. Cell Physiol Biochem. 2016;40:62-76.

-125 Assumpção CB, Calcagno DQ, Araújo TM, Santos SE, Santos ÂK, Riggins GJ, Burbano RR1, Assumpção PP: The role of piRNA and its potential clinical implications in cancer. Epigenomics 2015;7:975-984.

126 Rajasethupathy P, Antonov I, Sheridan R, Frey S, Sander C, Tuschl T, Kandel ER: A role for neuronal piRNAs in the epigenetic control of memory-related synaptic plasticity. Cell 2012;149:693-707.

127 Yuan Y, Wang H, Wu Y, Zhang B, Wang N, Mao H, Xing C: P53 Contributes to Cisplatin Induced Renal Oxidative Damage via Regulating P66shc and MnSOD. Cell Physiol Biochem 2015;37:1240-1256.

128 Wang QE, Han C, Milum K, Wani AA: Stem cell protein Piwil2 modulates chromatin modifications upon cisplatin treatment. Mutat Res 2011;708:59-68.

129 Wang Y, Gable T, Ma M Z, Clark D, Zhao J, Zhang Y, Liu W, Mao L, Mei Y: A piRNA-like Small RNA Induces Chemoresistance to Cisplatin-Based Therapy by Inhibiting Apoptosis in Lung Squamous Cell Carcinoma 2017;6:269-278.

130 Sai Lakshmi S, Agrawal S: piRNABank: a web resource on classified and clustered Piwi-interacting RNAs. Nucleic Acids Res 2008;36:D173-D177.

131 Betel D, Sheridan R, Marks DS, Sander C: Computational analysis of mouse piRNA sequence and biogenesis. PLoS Comput Biol 2007;3:e222.

132 Zhang Y, Wang X, Kang L: A k-mer scheme to predict piRNAs and characterize locust piRNAs. Bioinformatics 2011;27:771-776.

133 Brayet J, Zehraoui F, Jeanson-Leh L, Israeli D, Tahi F: Towards a piRNA prediction using multiple kernel fusion and support vector machine. Bioinformatics 2014;30: i364-370.

134 Wang K, Liang C, Liu J, Xiao H, Huang S, Xu J, Li F: Prediction of piRNAs using transposon interaction and a support vector machine. BMC Bioinformatics 2014;15:419.

135 Seyeddokht A, Aslaminejad A A, Masoudinejad A, Nassiri M, Zahiri J, Sadeghi B: Computational Detection of piRNA in Human Using Support Vector Machine. Av J Med Biotechnol 2016;8:36-41.

136 Liu YJ, Zhang JY, Li AM, Liu ZW, Zhang YY, Sun XH: Detection of Piwi-interacting RNAs based on sequence features. Gen Mol Res DOI: 10.4238/gmr.15028638. 